\title{
A Study on the Governance Model in the Sustainable Development of Chinese Non-governmental Universities and Colleges
}

\author{
Qiu Ziling \\ Business School \\ Zhejiang University City College \\ Hangzhou, China \\ 460434165@qq.com
}

\author{
Li Jiming* \\ Business School \\ Zhejiang University City College \\ Hangzhou, China \\ lijm@zucc.edu.cn
}

\begin{abstract}
As the social changes and education reforms in recent years, Chinese non-governmental institutions of high education have played an essential role in China's higher education. Whether the governance structure is perfect and reasonable has an increasing influence and restriction on the sustainable development of Chinese non-governmental universities and colleges. By employing the methodology of literature analysis and comparative analysis, this paper analyzes the problems and the causes of the internal and external governance structure in the development process of China's nongovernmental universities and colleges based on the national condition and the present development situation of China's nongovernmental higher education, and some solutions are proposed. In the end, the author provides some suggestions for the governance model in China which includes reasonable positioning of the government's role and functions, introducing market management mechanism and increasing social participation.
\end{abstract}

Keywords-Non-governmental universities and colleges; Sustainable development; Governance model; Higher education

\section{INTRODUCTION}

Any organization cannot operate without governance. As American educator Boyer indicated that effective management is the basis for a university to become an effective group. (Jing, 2008). Similarly, governance is also significant to Chinese nongovernmental universities and colleges as they are established according to the market economic system. The term, governance of non-governmental universities and colleges, is associated with an interaction process among the government, colleges, community groups, markets and students, which develop coordinately with public colleges by using complete systems. Those reasonable and complete systems of governance include both internal and external aspects. As Sun (2004) pointed, a perfect external governance pattern of nongovernmental universities and colleges should combine complete legal systems, scientific macro management, efficient intermediaries, etc. The government, market, social organizations and policies are core of the external governance pattern [1]. On the other hand, the internal governance pattern refers to policies, administration and supervision systems implemented by educational institutions, in which the board of directors, the principal, board of supervisors and the university charter are the key components. However, with the growth of the economy, the expansion in colleges and the further reformation in higher education, private colleges in China have encountered a substantial number of difficulties in education systems which deter their development. This paper will analyze problems and causes of the internal and external governance structure of Chinese private colleges in its process of development based on current situations of China's national condition and private higher education. Moreover, this paper also provides measures to complete governance model for nongovernmental universities and colleges in China [2].

\section{Current Situation And Problems in the Governance OF PRIVATE COLLEGES IN CHINA}

Over the past 30 years, the governance of nongovernmental universities and colleges in China has made great achievements which have developed with Chinese characteristics. The governance can be divided into two aspects: external governance and internal management [3]. However, being not mature enough, the external governance mechanisms fails in optimization and the internal one are also underdeveloped.

\section{A. Problems in External Governance}

- Underdeveloped Legal Systems and Regulations. Since 1982, the government in China has implemented legal systems to encourage the society to set up private colleges. However, there are still some problems. For example, underdeveloped legal regulations and the scarcity in conflict-solving systems mainly deter the governance. Additionally, the relevant system failed to regulate the nature of privately-run colleges, the definition of property rights, and the return on investment explicitly [4]. In this way, legal person property and the investors' interests cannot be wellprotected.

- Imbalanced Government's Public Policy and Implicit Role of the Government. Scarce financial support from

Li Jiming is the corresponding author. 
the government and the preferential enrollment policies inclined to public colleges increase the difficulty for non-governmental universities and colleges. In addition, offside, misplacement and vacancy problems exist in the Chinese government in the process of governing non-governmental universities and colleges, which means the role of the government is implicit. Moreover, due to the government's micro-interventions, which possesses characteristics of a planned system, private-operated colleges cannot develop flexibly. Those micro-interventions include setting a unified enrollment ratio, majors, fees and even interfering decision-making of Sino-foreign cooperative education.

- Incompletion and Responsibility-loss Problems in Nongovernmental higher Education Intermediaries and Organizations. Although there are education associations and research institutes supporting private colleges, problems like lacking intermediary organizations with functions of evaluating, certificating, auditing property, collecting information and publication of private-established universities remain unsolved. Under this circumstance[5], it is difficult for the government to directly evaluate private colleges and universities, because those organizations failed to show their responsibilities in proper consultation, coordination, supervision, evaluation, examination etc., thereby leading to a low social recognition towards education intermediaries and organizations. Therefore, establishing effective private higher education intermediary organizations is of great importance in order to achieve the scientific and democratic democratization of private higher education.

\section{B. Problems in Internal Governance}

- The Principal Responsibility System under the Leadership of the Board of Directors. After 2002, China further strengthened the requirements on the governance structure of non-governmental universities and colleges, generally, private-established colleges have set up board of directors since then. However, the system of board of directors is likely to be a "nominal" one: first, institutions are "fictitious"—some private colleges have not set up a real board of directors or colleges are owned by natural person; second, members are "fictitious"-without the real existing members, colleges fabricate names of members of the board of directors [6]. Third, the board of directors failed to undertake responsibilities like decision-making, or even degenerate into the advisory institutions.

- Unreasonable Composition Structure of the Board of Directors that Lacks "Masters and Talent". In today's society, there are few representatives of staff members and parents in the board of directors, who can help to achieve the relative balance between the interests of organizers and faculty. In addition, Most of the principals in private colleges may not be equally qualified, and it is also hard to find masters and talent. This is because government officials, especially the well-known university management candidates, are at an advantage in principal selections; second, compared with academic statures, management visibility would be ignored.

- Unclear Accountability in the Board of Directors and Principals. There are generally three types of situations in which the responsibilities of the board of directors and principals are unclear. The first one is that the overwhelming power of the board of directors often interferes with or even replaces the position of principal, which is in an ultra-power phenomenon. The second is that the overwhelming power of the school principal, causing difficulties for the board of directors to monitor the principal and lose control of the school's major decisions. The third is the combination of school managers and directors. This prevailing phenomenon can leads to the over-centralized power in the board of directors. At present, the relevant laws in China have not recognized the establishment of supervisory board as a compulsory for the management of private schools. According to the survey [7], among the 45 private universities being surveyed, there are only 8 schools that have set up permanent supervisions independently, accounting for less than one fifth. However, the number of non-governmental institutions that have not set up supervisions reaches 37 , accounting for more than $80 \%$ (Dong, 2010).

In addition to problems mentioned above, there are two problems in the regulations of the university: First, private colleges and universities do not have a university charter to follow; Second, regulations in a substantial number of colleges and universities are not effectively implement those regulations.

\section{Typical Governance Models of Private Colleges IN CHINA AND INTERNATIONAL GOVERNANCE EXPERIENCES}

According to previous literature and current analysis of private colleges, there are three basic patterns for the governance of private colleges: the human capital dominated model, the capital-dominated model and the integrated control model.

\section{A. The Human Capital Dominated Model}

Human capital here refers to special talent, who possesses administrative resources, have the experience of running schools or abilities to attract donations. However, in the governance of non-governmental universities and colleges, resources or abilities are owned by the sponsors, so this model can cause some problems. First, "unilateral governance" may occur when power of human capital are relatively strong, such as Beijing Urban College and Private Hualian College, which are owned by some retired professions. Second, operated by one or several individuals, private colleges cannot achieve overall development because of owners' personal traits, preferences or knowledge. 


\section{B. The Capital-dominated Model}

Controlled by the investors, this capital-led model's nonprofit characteristic has been suspected because it conflict with invests' private interests.

TABLE I. TYPICAL NON-GOVERNMENTAL COLLEGES BASED ON CAPITAL-DOMINATED MODEL

\begin{tabular}{|c|c|}
\hline $\begin{array}{c}\text { Non-Governmental Universities } \\
\text { and Colleges }\end{array}$ & External Investment Companies \\
\hline Dalian Art College & $\begin{array}{l}\text { Dalian Hongde Entertainment } \\
\text { Corporation }\end{array}$ \\
\hline $\begin{array}{l}\text { Liaoning University of International } \\
\text { business and Economics }\end{array}$ & $\begin{array}{l}\text { Investors are legal persons in } \\
\text { college }\end{array}$ \\
\hline Beijing Geely University & $\begin{array}{l}\text { Sponsored by Geely Co. (chairman: } \\
\text { Li Shufu) }\end{array}$ \\
\hline Qilu Medical University & $\begin{array}{l}\text { Sponsored by Shangdong Lushang } \\
\text { Co. }\end{array}$ \\
\hline $\begin{array}{l}\text { Dalian Neusoft University of } \\
\text { Information }\end{array}$ & $\begin{array}{l}\text { Invested by Neusoft Co. and Yida } \\
\text { Co. }\end{array}$ \\
\hline Dalian Art College & $\begin{array}{l}\text { Dalian Hongde Entertainment } \\
\text { Corporation }\end{array}$ \\
\hline Yantai Nanshan University & Nanshan CO. (private-owned) \\
\hline $\begin{array}{l}\text { Minnan University of Science and } \\
\text { Technology }\end{array}$ & $\begin{array}{l}\text { Established by Shishi Xingda Co. } \\
\text { and Changchun University of } \\
\text { Science and Technology }\end{array}$ \\
\hline Xi'an Siyuan University & $\begin{array}{l}\text { Sponsored by Xi'an Jiaotong } \\
\text { University Industry Co. }\end{array}$ \\
\hline $\begin{array}{l}\text { Hunan International and Economics } \\
\text { University }\end{array}$ & $\begin{array}{l}\text { Invested by Hunan Lieying Industry } \\
\text { Co. }\end{array}$ \\
\hline Nanchang Institute of Technology & $\begin{array}{l}\text { Invested by Nanchang Aerospace } \\
\text { Science and Technology Corp., Ltd. }\end{array}$ \\
\hline Jiangxi University of Technology & $\begin{array}{l}\text { Invested by Yuguo and collaborate } \\
\text { with business owners and educators } \\
\text { from the US. }\end{array}$ \\
\hline Anhui Xinhua University & Invested by Anhui Xinhua Co. \\
\hline Shanghai Jian Qiao University & Invested by Jianqiao Co. \\
\hline Anhui Sanlian University & Invested by Sanlian Co. \\
\hline $\begin{array}{l}\text { Shanxi Institute of International } \\
\text { Trade \& Commerce }\end{array}$ & Invested by Buchang Co. \\
\hline Tianjing Tianshi College & Tianjing Tianshi Co. \\
\hline
\end{tabular}

\section{Integrated Control Model}

Integrating the features of capital, human capital and government power, this model is conducted by a minority of colleges. There are four schools can be classified as typical integrated control model: Zhejiang Yuexiu Institute of Foreign Languages, Zhejiang Wanli College, Zhejiang Shuren College and Shanghai Shanda College.

\section{Overseas Experiences of External Governance Structure in Private Universities}

There are two main reasons for overseas private colleges like Stanford, Harvard University to become internationally renowned universities. The first one is that the college integrates a significant number of elite talents. The other important reason is their increasingly perfect governance structures of private colleges. Therefore, the outstanding governance experience of private universities in foreign countries is useful for the sustainable development of private universities in China.

Western universities mainly have three categories of governance: the governance model of universities in the United States, France and Japan. Among them, the relationship between higher education institutions and the government is least connected in the US. Colleges and universities in the different states have always had strong autonomy. Compared with this, French universities have closer relations with the government and have the tradition of governing universities through government legislation. Therefore, Institutional intervention is even stronger. Such intervention is based on a sound legal system and academic power remains independent. Influenced by oriental cultural tradition, universities and governments in Japan are most closely connected. In today' $\mathrm{s}$ society, the Japanese government once again enhances the centralized management of the universities through laws and regulations.

Regarding discussions above, there are similarities in the governance of universities from different countries: As for external governance, non-governmental universities all pay attention to the legal systems and regulations. Similarly, finding balance between executive and academic power via launching a set of perfect decentralization systems and collaboration model is common in internal governance. There are three main forms of governance model structure: management, academic union and common governance. Additionally, these models change with time. The government manages the colleges through clear legal procedures and avoids direct administrating, which provide the autonomy for private universities without involving in the internal micromanagement. 


\section{CONCLUSION AND DISCUSSION}

\section{A. Optimizing the External Governance Model}

- $\quad$ The government should take reasonable positions and modify its responsibilities. To develop private education, role of supervision and guidance is more important to the government. Aiming at improving its responsibilities, the government should: First, to increase direct subsidies for private universities; second, to increase the indirect support for private colleges and universities. As non-profit institutions, private colleges should possess equal access to public resources as public universities do. In addition, expanding accesses to public resources in nongovernmental colleges can help them to alleviate the barrier of resource scarcity.

- Introduce Rational Market System and Standardize the Private Education Market. The priority to introduce a reasonable of market-oriented system is to organize an orderly education market. To cultivate a competitive market, the government should: First, cultivate the market players. The government should encourage the investment for social education, expanding investment accesses, thereby creating a favorable environment for the development of private colleges and universities. Second, complete market system. It is necessary for the government to implement open, harmonious, and fair market regulations that improve competition and break the monopoly of educational industries, thereby creating a win-win competitive education system for higher education. Third, correspond with international standards. This is because collaboration can help private colleges in China to participate in international competitions and enhance the competitiveness.

- Cultivate China's Private Higher Education Intermediary Organizations. First, it needs laws and regulations to support. Second, establishing various types of private higher education intermediary organizations is a must. Third, the government should improve the authority of private higher education intermediary organizations. Fourth, non-governmental colleges and universities should support the work of these intermediary organizations.

\section{B. Improve the Internal Governance Model}

- Improve the Responsibility System under the Leadership of the Board of Directors and Enhance the Functions of the Board of Directors. First, it is significant to optimize the composition structure of the board of directors, increasing the professional level of the board of directors and enhance the scientific decision-making of the board of directors. Second, improving the regulation of the Board of Directors, standardizing operational procedures and enhance the normativity and decision-making procedures will be useful. Third, the relationship between the principal and the board of directors should be clarified clearly.
- Improve the Principal Responsibility System and Create a Professional Team of Principals. First, principal selection systems should be built up in order to actively promote the professionalism of university presidents. Second, establishing the principal term system, responsibility system and interest-sharing system to ensure that the principal is qualified to exercise their powers is of great importance. This is because whether the principal has excellent management skills is a determinant to the sustainable development of private universities.

- Improve the Governance and Supervision System of Private Colleges and Universities. First, the principals accountability system in colleges to strengthen the supervision of principals and implementing agencies should be implemented; second, the system of faculty and staff representatives should be completed, as well as staff and students interest appeal systems; third, it is indispensable to establish a board of supervisors, thereby strengthening the supervision of the school board of directors and avoiding overlapping functions between the board of supervisors and the independent directors; fourth, improving the supervisor system, and form a supervisory team rotation system is needed.

\section{REFERENCES}

[1] Elaine EI. Khawas, External Scrutiny: US Style, in Tony Becher: Government and Professional Education, Society for Research into Heand Open University Press, 1994.

[2] Ohio Board of Regents, Higher Education Governance Structures: Coordinating Boards VS. Governing Boards, Ohio Board of Regents, September 2003.

[3] J. Ran, "Reconstruction of the Relationship between the Gvernment and Non-governmental Colleges Based on the Governance Theory", Changbai Journal, pp.141-143, June 2008. (In Chinese)

[4] S. BoYing, Contemporary Local Governance. Beijing: China Renmin University Press, 2004, pp.19. (In Chinese)

[5] D. Shen Zu, Governance to Non-governmental Colleges: A Study on the Governance of Legal Person in non-governmental colleges, Beijng: Education and Science Press, 2010, pp.118. (In Chinese)

[6] L. Wang guo, L, Man Qin, "The governance model and forming mechanism in non-governmental colleges: based on the development", Higher Education Exploration, pp. 150-154, May 2014. (In Chinese)

[7] L. Song, "A study on the governance model of non-governmental colleges - based on the stakeholder", Journal of Yangzhou University: higher education research version, pp.18-21, May 2008. (In Chinese) 